\title{
BERGSON'S REFORMATION OF PHILOSOPHY
}

\author{
Keith Ansell-Pearson
}

University of Warwick

\begin{abstract}
In this essay I take my cue from Pierre Hadot who argued that for him as a young student, 'Bergsonism was not an abstract, conceptual philosophy, but rather took the form of a new way of seeing the world'. Philosophy for Bergson has two main aims: (i) to extend human perception; (ii) to enhance the human power to act and live. Both are at work in his texts and explicitly stated as the ambit of philosophy in Creative Evolution. I examine some core aspects of Bergson's reformation of philosophy, in which he is inspired by the ambition of taking philosophy out of the school, including the disputes between the different schools of philosophy, and bringing it into more intimate contact with life. The new knowledge we acquire will do two things: it will enrich philosophical speculation - we see for the sake of seeing and the enrichment an enlarged perception offers us - and it will nourish and illuminate everyday life, including enhancing our power to act and live.
\end{abstract}

Keywords: Philosophy; The Art of Life; Intuition; Duration; Science; Metaphysics; Intelligence; Sympathy.

Resumo: Neste artigo sigo uma sugestão de Pierre Hadot pela qual ele, desde que era um jovem estudante, entendia que "o bergsonismo não era uma filosofia abstrata e conceptual, mas uma nova maneira de ver a si e ao mundo". A Filosofia para Bergson possui assim dois objetivos principais: (i) ampliar a percepção humana; (ii) aprimorar a capacidade humana de agir e de viver. Examino alguns aspectos centrais da reforma bergsoniana da Filosofia, cuja ambição é levar a Filosofia além da academia, inclusive das disputas entre diferentes escolas filosóficas. O novo conhecimento que assim obtivermos nos possibilitará duas coisas: aprimorará a especulação filosófica - 0 que contribui para uma ampliação de nossa percepção -, estimulará e iluminará a vida cotidiana, inclusive aprimorando a nossa capacidade de agir e de viver.

Palavras-chave: Filosofia; Arte de Viver; Intuição; Duração; Ciência; Metafísica; Inteligência; Simpatia.

In this essay I take my cue from Pierre Hadot (1922-2010) who has argued that for him as a young student of philosophy at the Sorbonne, 'Bergsonism was not an abstract, conceptual philosophy, but rather took the form of a new way of seeing the world' (Hadot 1995: 278). Philosophy for Bergson has two main aims: (i) to extend human perception; (ii) to enhance the human power to act and live. Both are at work in his texts and explicitly stated as the ambit of philosophy in Creative Evolution. In his corpus Bergson is deeply preoccupied with the reformation of philosophy in particular and the 
reformation of education in general. He is inspired by the ambition of taking philosophy out of the school, as he puts it, including the disputes between the different schools of philosophy, and bringing it into more intimate contact with life (CM 126). Indeed, if we follow the contours of 'intuitive life' with its special kind of knowledge, then the promise is opened up of bringing an end to 'inert states' and 'dead things': 'nothing but the mobility of which the stability of life is made' (CM 127).

Such knowledge will do two things: it will enrich philosophical speculation - we see for the sake of seeing and the enrichment an enlarged perception offers us - and it will nourish and illuminate everyday life (it will enhance our power to act and live, for example). In order to restore our contact with life it is necessary to conquer the deadening world of habit: 'For the world into which our senses and consciousness habitually introduce us is no more than the shadow of itself: and it is as cold as death' (CM 128). In his essay on 'Good Sense and Classical Studies' Bergson contends that the stubborn clinging to habits (raised to the status of laws of life) is to repudiate change and allow one's vision to be distracted away from the movement that is the condition of life (BKW 424).

Bergson forges a crucial distinction between the provinces of science and philosophy with the former concerned with well-being, and at most pleasure, and the latter holding out the promise of delivering us over to joy. Bergson does not wish to denigrate the importance of the convenient life, the life of well-being, but it is clear he sees a superior reality in the joyful existence since it is here that we encounter creative life, including the creation of self by self. It is this set of concerns, centred around Bergson's attempt to revitalise philosophy's investment in the art of life, that I wish to explore in this essay. The task is to extend perception and to effect a conversion of attention. The method for doing this is intuition, and the overriding aim is to become accustomed to seeing all things sub specie durationis: in this way what is dead comes back to life, life acquires depth, and we come into account with the original impetus of life that serves to encourage us to create new things. The task of philosophical education is to become a master in the art of living. Let me now explore in more detail Bergson's conception of philosophy.

\section{Philosophy}

Bergson's contribution to a reformation of philosophy consists primarily of his attempt to provide an enlarged perception of the universe. For Hadot, Bergson's thinking effects a 'displacement of attention' - similar in character to the phenomenological reduction or epoche as articulated in the work of Merleau-Ponty - and that amounts to a 'conversion', that is, 'a radical 
rupture with regard to the state of unconsciousness in which man normally lives' (1995: 254). What is being overturned is the 'utilitarian perception we have of the world', which conceals from us the world qua world. Hadot contends in closing his discussion of Bergson:

Aesthetic and philosophical perceptions of the world are only possible by means of a complete transformation of our relationship to the world: we have to perceive it for itself, and no longer for ourselves (ibid.).

This statement in in accord with a core tenet of Hadot's thinking, constituting one of the main features of the 'cosmic consciousness' he associates with the Stoic way of living, in which we make the conversion from prosaic subjective everydayness to the standpoint of universality and objectivity.

Bergson's contribution here is of a specific kind. He wants to show how, through an appreciation of the evolution of life, philosophy can expand our perception of the universe. How, though, is it possible to think beyond the human condition and outside of its particular framing of reality? This is where Bergson appeals to evolution itself and stresses that the line of evolution that has culminated in the human is not the only line. His idea seem to be a radical one, namely, that there are other forms of life-consciousness that express something that is immanent and essential in the evolutionary movement, and the critical task is to then bring these other forms into contact or communication with the human intellect. Bergson poses the question: would not the result be a consciousness as wide as life?

What does he have in mind? Bergson is suggesting that it is possible to cultivate, through intellectual effort, a perception of life where we experience something of the very impetus of creative life itself or what he describes as the push of life and that has led to the creation of divergent forms of life from a common impulsion, such as plant and animal. In short, philosophy is that discipline of thinking that tries to make the effort to establish contact with the vitality and creativity of life and involving novelty, invention, process, and duration.

In the introduction to Creative Evolution Bergson tackles the objection that may be raised against the project he is inviting us to pursue: will it not be through our intellect and our intellect alone that we perceive the other forms of consciousness? In answer to this objection he points out that this would be the case if we were pure intellects, but the fact is, he thinks, we are not. Around our conceptual and logical modes of thought, and that have moulded themselves on certain aspects and tendencies of the real, there remains a vague nebulosity that is made of the same substance out of which the luminous 
nucleus we call the intellect has been fashioned. Here we shall find, he thinks and hopes, certain powers - powers of insight, vision, and perception - the nature of which we have only an indistinct feeling when we remain shut up in ourselves and exist as closed beings. The task of philosophy is to make these powers clear and distinct, Bergson says in a clear reference to Descartes.

Bergson conceives philosophy as the discipline that 'raises us above the human condition' (la philosophie nous aura élevés au-dessus de la condition bumaine') (O 1292; CM 50) and makes the effort to 'surpass' (dépasser) it (O 1425; CM 193). In Creative Evolution Bergson conceives philosophy as 'an effort to dissolve again into the whole'. Moreover: 'Intelligence reabsorbed into its principle, may thus live back again in its genesis' (CE 123). Such a method of thinking has to work against the most inveterate habits of the mind and consists in an interchange of insights that correct and add to each other. For Bergson, such an enterprise ends by expanding the humanity within us and even allowing humanity to surpass itself by reinserting itself in the whole (CE 124). This is accomplished through philosophy for it is philosophy that provides us with the means (methods) for reversing the normal directions of the mind (instrumental, utilitarian), so upsetting its habits. This reveals itself to be something of an extraordinary endeavour since it means bringing the human intellect into rapport with other kinds of consciousness.

Bergson claims that the theory of knowledge and theory of life are to be regarded as inseparable. If we do not place our thinking about the nature, character, and limits of knowledge within the context of the evolution of life then we risk uncritically accepting the concepts that have been placed at our disposal. It means we think within pre-existing frames. We need, then, to ask two questions: first, how has the human intellect evolved? (since it does not simply think for the sake of it but has evolved as an organ of action and utility), and second, how can we enlarge and go beyond the frames of knowledge available to us?

Bergson has a specific conception of the human intellect and of matter. The intellect has moulded itself on the geometrical tendency of matter and so as to better further its instrumental manipulations of matter. His chief claim is that the intellect has to be viewed within the context of the evolution of human life and that when we do this we can better grasp its limits and how to think beyond it. The task, in short, is to attempt to think beyond the representational and spatial habits of the intellect.

In his writings Bergson advances several conceptions of philosophy, of what it is and its chief tasks. Sometimes he will stress its capacity to enable us to see: philosophy exists to extend our perception of the universe. At other times he will also express anxiety over philosophy's lapse into contemplation 
and stress its ability to enhance our power to act and to live. On the one hand, the paradoxical theoretical task of philosophy is, above all, to find some 'absolute' in the moving world of phenomena. On the other hand, it is more dynamic than this and, through this restoration of the absolute we will gain in a feeling of greater joy and power. Bergson writes:

Greater joy because the reality invented before our eyes will give each one of us,
unceasingly, certain of the satisfactions which art at rare intervals procures for
the privileged; it will reveal to us, beyond the fixity and monotony which our
senses, hypnotized by our constant needs, at first perceived in it, ever-recurring
novelty, the moving originality of things. But above all we shall have greater
strength, for we shall feel we are participating, creators of ourselves, in the great
work of creation which is the origin of all things and which goes on before our
eyes (CM 105).

Typically we exist - both in terms of our species history and our individual development - as slaves of certain natural necessities. Philosophy is a practice and a discipline that can enable us to go beyond the level of necessities and enable us to become 'masters associated with a greater Master' (CM 105-6).

We exist as masters in two main forms: through science and the mastery of matter and through philosophy and the mastery of life. One is more free than the other for Bergson: the mastery of matter is part of the human condition and is a necessity for us, but the mastery of life takes us beyond the human condition and represents a free activity. Moreover, whilst the former activity serves to provide us with security and is bound up with securing a life of convenience (s), the latter is something different. Philosophy can become complementary to science with respect to both speculation and practice. More than this, it supplements science since science offers us only the promise of well-being and the pleasure of it - philosophy can give us joy, and this joy is bound up with the move beyond the limited character of the human condition. This supplementary aspect of philosophy provides us with an insight into the role Bergson accords to intuition. Let me now focus on this topic.

\section{Towards Intuition}

Bergson calls intuition the attention that the mind gives to itself 'over and above, while it is fixed upon matter, its object' (CM 78). It is a 'supplementary attention' that can be methodically cultivated and developed. We need to begin by noting the distinction between life and matter that characterizes Bergson's thinking. For the most part he writes of 'inert matter', though he also refers to 'organized matter' and also of matter as made up of vibrations and to which slight durations can be attributed (CE 201). However, 
marking a distinction between matter and life is a central feature of Bergson's thinking, whether he is attempting to explain the character of evolution or exploring the meaning of the comic ${ }^{1}$. Roughly speaking, it works as a distinction between inertia and vitality, between rigidity and suppleness, between automatism and creative effort, between necessity and freedom, and so on. However, matter and life/'consciousness' (delay, hesitation, a latitude of choice) are not to be explained apart from one another, and the two are said to have a common source (ME 17, 20). If the determinism of matter were absolute, to the point of admitting no relaxation and showing no elasticity (which Bergson thinks it does), then life would be an impossibility. Life is an insinuating energy, an impetus, that draws matter away from pure mechanism but only by first adopting this mechanism; life installs itself in matter which had already acquired some of the characters of life without the work of life' (ME 20). However, if matter were all that there is then it would have stopped at this point. This is akin, Bergson thinks, to the work of our scientific laboratories where we are seeking to manufacture matter that resembles living matter and is an enterprise that one day, he says, may well be successful. However, he adds, "we shall reproduce, that is to say, some characters of living matter; we shall not obtain the push in virtue of which it reproduces itself and, in the meaning of transformism, evolves" (ibid.).

We also need to note that Bergson is puzzling on action and we can only resolve the difficulties generated by the puzzle by recognising that he is putting forward different types of action and activity. This is best seen in the way he seeks to demarcate the difference between metaphysics (and intuition) and science (and intelligence). Both are related to action but the action is different in the two cases. So, Bergson writes:

To metaphysics, then, we assign, a limited object, principally spirit, and a special method, mainly intuition. In doing this we make a clear distinction between metaphysics and science. But at the same time we attribute an equal value to both. I believe they can both touch the bottom of reality. I reject the arguments advanced by philosophers, and accepted by scholars, on the relativity of knowledge and the impossibility of attaining the absolute (CM 37).

It is important to appreciate that Bergson is positing between science and metaphysics a difference of method and not a difference in value (CM 43-

1 For Bergson the comic does not exist outside what is human and is to be explained in terms of the mechanical being encrusted on the living. He writes: 'The comic is side of a person which reveals his likeness to a thing, that aspect of human events which, through its peculiar inelasticity, conveys the impression of pure mechanism, automatism, of movement without life', H. Bergson, Laughter: an essay on the meaning of the comic, trans. Cloudeseley Brereton and Fred Rothwell (Kobenhavn \& Los Angeles: Green Integer, 1999), p.82. 
4). The task of metaphysics, as he conceives it, is to concern itself with the actual world in which we live and not with all possible worlds, so philosophy embraces realities (CM 44). Science for Bergson is attached to a specific task, one that he does not wish to negate the importance of, namely, the mastery of matter. Positive science relies on sensible observations as way of securing materials and it does this by elaborating, through methods and faculties, abstraction and generalization, in short it establishes the order of intelligence through judgement and reasoning. Its 'original domain' and its 'preferred domain' is the domain of inert matter, or of matter stripped of the vitality of life: it clings to the physico-chemical in vital phenomena rather than to what is really vital in the living' (CM 38). If our intelligence can be construed as the prolongation of our senses, then we can see the force of science and its aid to life, at least life in its aspect of calculability and manipulation. Prior to pure speculation - seeing for the sake of seeing - there is the imperative to live, and so life demands that matter be made use of, and this takes place through our organs (conceived as natural tools) and with tools, properly so-called, as artificial organs. Although science has pushed far the labour of intelligence it has not changed its essential direction, which is to make us masters of matter. Bergson argues that even when it speculates science continues to devote itself to acting, and here it is evident that he has a specific kind of action in mind, namely, action of a utilitarian and instrumental character. Bergson further holds that between intellect and matter there is 'symmetry, concord and agreement': 'On one hand, matter resolves itself more and more, in the eyes of the scholar, into mathematical relations, and on the other hand, the essential faculties of our intellect function with an absolute precision only when they are applied to geometry' (CM 39).

To break out of the social circle it will become necessary to appeal to experience. Experience is of two main kinds: if it is an affair of knowing material objects then we are dealing with exterior perception; if it is question of encountering the mind we refer to the name of 'intuition' and raising ourselves above our human state (CM 50). What of 'metaphysics'? Here Bergson holds that the task is 'to develop new functions of thought' (CM 41). The focus of metaphysics is with 'mind' and 'spirit', especially with ourselves and our internal lives. He acknowledges the difficulty: is it not, he asks, much more difficult to develop knowledge of oneself than it is knowledge of the external world? He adds:

Outside oneself, the effort to learn is natural; one makes it with increasing facility; one applies rules. Within, attention must remain tense and progress becomes more and more painful; it is as though one were going against the 
natural bent. Is there not something surprising in this? We are internal to ourselves, and our personality is what we should know best (CM 41).

Bergson notes, then, a point that is crucial to his own attempt to contribute to how philosophy can aid the art of living, namely, that within the field of instrumental action, a certain ignorance of self is what is found to be most useful and answers to a necessity of life since here we encounter a being, ourselves, that must exteriorize itself in order to act. Hence his claim that mind finds itself in a strange place when it encounters life, in contrast to its habitual feeling at home in the realm of matter (it knows what it must do when it comes to acting in the world). He is not denying, of course, that when it comes to such effective action that we are distinguished from animals, for example, in having capacities that enable us to reflect on our actions. But, he notes, nature requires that we only take a quick glance at our inner selves: 'we then perceive the mind, but the mind preparing to shape matter, already adapting itself to it, assuming something of the spatial, the geometric, the intellectual' (CM 42). It is in this context of problems that he appeals to intuition as a mode of mental attentiveness: 'This direct vision of the mind by the mind is the chief function of intuition, as I understand it' (CM 42). But we still do not know what this intuition is and how it can amount to a new function of thinking. Part of the difficulty is our reliance on metaphor and ready-made concepts as a way of thinking reality and reflecting on our experience of the real. This is why Bergson stresses that in order to gain access to intuition - since there is nothing immediate about it as a method - an entire labour of clearing away is required and as a way of opening up the way to 'inner experience': 'True, the faculty of intuition exists in each one of us, but covered over by functions more useful to life' (CM 47).

In order to gain access to the practice of intuition it is necessary to break with society, in particular with the subdivision and distribution of the real into concepts that society has deposited into language and for the sake of the convenience of existence. Society or the social organism cuts out reality according to its needs, and Bergson asks why philosophy ought to accept a division that in all probability does not correspond to the articulations of the real - except, of course, in terms of our mastery of matter. The challenge here for thinking about the art of living is a serious one: it means not accepting the claim, 'that all truth is already virtually known, that its model is patented in the administrative offices of the state, and that philosophy is a jig-saw puzzle where the problem is to construct with pieces society gives us the design it is unwilling to show us' (CM 50). Contra this position, Bergson maintains that in philosophy - and not only in philosophy - it is question of finding the problem and of positing it, rather than of solving it: '...stating the problem is not simply 
uncovering, it is inventing' (51). The difference between the two is paramount since in the one case we are uncovering what already exists actually or virtually and in the other case with what does not exist and might never have happened: 'Already in mathematics and still more in metaphysics, the effort of invention consists more in raising the problem, in creating the terms in which it will be stated' (51).

Intuition is not duration, but rather the movement by which thought emerges from its own duration and gains insight into the difference of other durations within and outside itself. It both presupposes duration, as the reality in which it dwells, but it also seeks to think it: '...to think intuitively is to think in duration' (CM 34). Without intuition as a method duration would remain for us a merely psychological experience and we would remain prisoners of what is given to us. Informing Bergson's thinking, therefore, is a philosophical critique of the order of need, action, and society that predetermine us to retain a relationship with things only to the extent that they satisfy our interest, and of the order of general ideas that prevent us from acquiring a superior human nature.

Bergson insists that his method of intuition contains no devaluation of intelligence but only a determination of its specific facility. If intuition transcends intelligence this is only on account of the fact that it is intelligence that gives it the push to rise beyond. Without it intuition would remain wedded to instinct and riveted to the particular objects of its practical interests. The specific task of philosophy is to introduce us 'into life's own domain, which is reciprocal interpenetration, endlessly continued creation' (CE 115). This is different to what science does when it takes up the utilitarian vantage point of external perception and prolongs individual facts into general laws. The reformed metaphysics Bergson wishes to awaken commits itself to an intellectual expansion of reflection and intuition is, in fact, intellectual sympathy.

For Bergson, then, the key move for thought to make lies in the direction of sympathy. By means of science intelligence does its work and delivers to us more and more the secret of life's material or physical operations. But this gives us only a perspectivism that never penetrates the inside, going 'all round life, taking from outside the greatest possible number of views of it...' (CE 176) By contrast, metaphysics can follow the path of intuition, which is to be conceived as 'instinct that has become disinterested, self-conscious, capable of reflecting upon its object and enlarging it indefinitely' (ibid.). Bergson has recourse to the example of the aesthetic to develop this insight. It is the aesthetic faculty that gives us something other than what is given for us by normal perception. The eye, he notes, perceives 
the features of the living in terms of an assembling and not as something involving mutual organization and reciprocal interpenetration: 'The intention of life, the simple movement that runs through the lines, that binds them together and gives them significance, escapes it' (177). It is just this intention that the artist, he says, seeks to regain, 'placing himself back within the object by a kind of sympathy... by an effort of intuition'. In his essay on Ravaisson, Bergson alludes to the importance of art for metaphysics:

\footnotetext{
The whole philosophy of Ravaisson springs from the idea that art is a figured metaphysics, that metaphysics is a reflection on art, and that it is the same intuition, variously applied, which makes the profound philosopher and the great artist' (CM 231).
}

It needs to be pointed out, however, that Bergson himself does not subscribe to the identification of art with philosophy. He holds that philosophical intuition goes further than aesthetic intuition since it is capable of capturing the vital before its dispersal into images (BKW 450). Aesthetic intuition has a limited character, which resides in the fact that it gives us only the individual case. He thus invites us to pursue an inquiry that is turned in the same direction as art, but 'which would take life in general for its object, just as physical science, in following to the end the direction pointed out by external perception, prolongs the individual facts into general laws' (CE 177). He concedes the obvious point, namely, that such a philosophy of life will never obtain a knowledge comparable to that which science acquires: 'Intelligence remains the luminous nucleus around which instinct, even enlarged and purified into intuition, forms only a vague nebulosity' (ibid.). In default of knowledge properly so-called, however, intuition provides us with a supplement that enables us to grasp that which intelligence fails to provide.

\section{Conclusion}

Bergson conceives of philosophy as an effort to dissolve into the whole. This dissolving has to be seen as the ultimate end of the task of thinking beyond the human condition. When Bergson appeals to a comprehension of 'the depths of life' he is referring to the possibility of going beyond the limitation of knowledge to appearances and understanding something of the essence of life, namely, life in terms of its dynamic evolutionary movement and as a whole. It is not necessary, he thinks, that we restrict ourselves to the mechanistic idea we have of life and that the understanding gives us, which is necessarily artificial and symbolical. On the one hand such a procedure makes the total activity of life reducible to the form of a certain human activity; on the other hand, this is 'only a partial and local manifestation of life, a result or by-product of the vital process' itself (CE 
xii). It is at this point in his argument that Bergson appeals to the endeavour of thinking 'beyond the human condition'. As he notes, 'the line of evolution that ends in man is not the only one (ibid.). He now evinces his key position on the question of extending human perception, and it is worth citing him at some length:

On other paths, divergent from it, other forms of consciousness have been developed, which have not been to free themselves from external constraints or to regain control over themselves, as the human intellect has done, but which none the less, also express something that is immanent and essential in the evolutionary movement. Suppose these other forms of consciousness brought together and amalgamated with intellect: would not the result be a consciousness as wide as life? And such a consciousness, turning around suddenly against the push of life which it feels behind, would have a vision of life complete...(ibid. xii)

Just what exactly is Bergson proposing? Before we look at this let us note that Bergson takes cognizance of an obvious objection to his proposal: how can we transcend the human intellect when it is through the intellect that we perceive other forms of consciousness? His response is to suggest that we are not, in fact, simply pure intellects and for this reason: around the conceptual and logical modes of thought there has remained 'a vague nebulosity, made of the very substance out of which has been formed the luminous nucleus that we call the intellect' (ibid.). This means that it becomes possible to locate certain powers of perception that are complementary to the understanding. Typically, and for the most part, these powers, of which we have only an indistinct sense, remain closed because we exist as closed creatures, so the aim, says Bergson, is to make them become 'clear and distinct' and show them to be at work in the evolution of nature. The task is one of learning 'what sort of effort they must make to be intensified and expanded in the very direction of life' (xiii).

For Bergson the task is to think life itself and in terms of its evolutionary movement. He clearly thinks that we can overcome the alienation of our closed existence and establish contact with other forms of life and with the evolutionary movement as a whole. As he puts it in the opening section of chapter three of Creative Evolution, 'Philosophy can only be an effort to dissolve again into the Whole' (La philosophie ne peut être qu'un effort pour se fondre à nouveau dans le tout) (CE 191). His idea is that we are immersed in an 'ocean of life' in which a beneficent fluid bathes us' and from where we draw the force to labour and to live (ibid.). It could be said that when we make the effort to go beyond the human condition we overcome our alienation from life. To practise philosophy in the sense of cultivating a new attention to, and 
perception of, the world is to experience something of the character of this overcoming: it makes contact with the whole of life possible.

\section{References}

BERGSON, Henry. Bergson Key Writings [BKW]. Ed. Keith Ansell-Pearson and John Mullarkey. London \& New York: Continuum Press, 2002.

. Creative Evolution [CE]. Translated by Arthur Mitchell. Lanham MD: University Press of America, 1983.

. The Creative Mind [CM]. Translated by Mabelle L. Andison. Totowa/New Jersey: Littlefield/Adams \& Co., 1965.

. Mind-Energy [ME]. Translated by H. Wildon Carr. Basingstoke:

Palgrave Macmillan, 2007.

. Oeuvres [O]. Paris: PUF 1959.

HADOT, P. Philosophy as a W ay of Life. Translated by Michael Chase. Oxford: Blackwell, 1995. 